barding by gunners 18,000 yards away to finally heel over this ship. As she sank to the bottom of the sea, bands on the surrounding ships played "The Star-Spangled Banner" while the men on deck stood at attention in respect for this gallant ship.

There have been four ships named after the state of Iowa. The first was a post-Civil War wooden screw sloop launched in July of 1864. Originally named the Ammonoosuc, the sloop was renamed the Iowa on May 15, 1869. It was sold to a private concern (Hubbel \& Porter of Syracuse) on September $27,1883$.

The battleship U.S.S. Iowa III was under construction in 1923, when the Arms Limitation Treaty was signed. She was ordered dismantled and was sold for scrap when she was only one-third complete.

The U.S.S. Iowa IV was launched on August 27, 1942, at the Navy yard in New York, and was fittingly christened by Mrs. Henry A. Wallace, wife of the then Vice-President of the United States. This ship was the first of the Navy's super 45,000 -ton battleships to be built, and she served in World War II. Retired in 1958, the lowa $I V$ is in the mothball fleet at the Navy yard in Philadelphia.

\title{
The Library's Roving Reporter
}

\author{
by Lida L. Greene
}

Hitching racks have given way to parking meters; tractors trundle along the streets instead of farm wagons; and for the young, Beatle records and football have replaced the singing school and autumn hayrides. There is, however, something about the smaller county seat towns of Iowa that is almost changeless. A block from the square there is still the Victorian house a doctor built for his bride; and an honest stone building not far away houses the picture of a canny Scot named Carnegie whose millions seeded the midwest with libraries. At a court house built in '73 or '89 or 1904, busy people will always take time to locate a land patent volume, a first marriage index, or go to the vault in the basement for 1855 tax records. 
You guessed it! It has been an Iowa vacation-a real buswoman's holiday. Need I say it was an exciting and "profitable" one for the Iowa State Historical Library. In Marshall County it was Civil War manuscripts; in Sigourney, a check of land patents and early tax records against names found in an 1844 census; in Lee County, a search for the Latter Day Saint who led one of the first parties of Mormons across lowa in 1844-45.

Let me tell you some of the bonuses on my Iowa trip. The Civil War journal loaned by C. E. Wetherbee of Marshall County contained one of the best descriptions of army camp life in the 1860 's that I have ever seen. The Keokuk Library vault brought forth a host of treasurers. Among them was an account book of a fur trading post that was established long before the Black Hawk War and the first ceding of Iowa lands to the government; the cite of the post was at the triangle formed by the Mississippi and Des Moines rivers. I am pleased to report that we have been promised the opportunity of microfilming many of these original materials for the growing collection in the Iowa Department of History and Archives.

There is not space to name all the pleasant and helpful people I met on my Iowa safari. Let this be one way of saying, "Thank you." I shall remember all of you and the towns along the way that before had been only pin points on maps or names in an aged history book. Listen to them: Ainsworth, Cotter, Grandview, Toolesboro, Montrose, Birmingham. They carry the sound and shape of Iowa's beginnings. It was September; 1964, but I could see Mississippi ferries, breaking plows, saddle-bag ministers and lawyers, and young families making a new world for themselves in the frontier that was Iowa.

Let me remind you to look for the story of the Historical Library in the coming biennial report of the Department of History and Archives. Before I forget, if you are driving through Sigourney this fall, turn west at the southwest corner of the city square. Just a block away is the house the doctor built for his bride. It still wears a prideful iron-lace coronet. 
Copyright of Annals of Iowa is the property of State of Iowa, by \& through the State Historical Society of Iowa and its content may not be copied or emailed to multiple sites or posted to a listserv without the copyright holder's express written permission. However, users may print, download, or email articles for individual use. 